\title{
A Political Agenda in Conflict with Environmental Protection: A Critical Policy Essay from Brazil
}

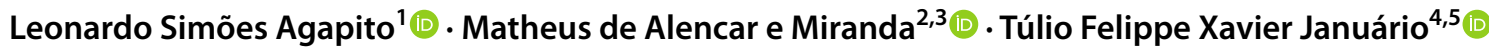

Received: 13 February 2021 / Accepted: 10 December 2021 / Published online: 25 January 2022

(c) The Author(s), under exclusive licence to Springer Nature Switzerland AG 2021

\begin{abstract}
Current Brazilian policies on environmental protection have become a worldwide concern since President Bolsonaro's election in 2018. Not only have his speeches been aggressive and critical of environmental protections, but many of his actual decisions have shown a very dangerous negligence of populations and interests affected by environmental harms. As a consequence, different environmental crises have plagued the country without any adequate response by public agencies or emergency plans to diminished harms. This essay uses a regulatory approach to demonstrate how the recent large withdrawal of environmental protection instruments in Brazil have supported a harmful and unlawful political agenda. First, we reconstruct the historical narrative of Brazilian environmental policy between the years 2018 and 2021, demonstrating through journalistic reports and social organizations' alerts, how the speeches, actions and omissions of the Brazilian government may have contributed to the present environmental situation. Using an environmental justice perspective, we demonstrate a lack of legitimate influence on political decisions related to environmental protection. Subsequently, we discuss the existing legal instruments to respond to the political abuses in the Brazilian legal system, in order to demonstrate their insufficiency to deal with this scenario. Finally, we evaluate international criminal law as a possible answer to the ongoing environmental abuses in Brazil.
\end{abstract}

Keywords Environmental crimes $\cdot$ Brazil $\cdot$ Political agenda $\cdot$ Amazon $\cdot$ Pantanal $\cdot$ Forest fires

\section{Introduction}

During the 1960s, the Brazilian military regime supported different initiatives of "Amazon's colonization", by offering financial credits and tax benefits for big companies (Martins,

Túlio Felippe Xavier Januário

tuliofxj@gmail.com

Leonardo Simões Agapito

leoagapito@gmail.com

Matheus de Alencar e Miranda

matheus.alencarm@gmail.com

1 University of São Paulo - USP, São Paulo, Brazil

2 Rio de Janeiro State University - UERJ, Rio de Janeiro, Brazil

3 District Attorney's Office of the State of Rio de Janeiro, Rio de Janeiro, Brazil

4 University of Coimbra, Coimbra, Portugal

5 Fundação para a Ciência e a Tecnologia - FCT, Lisbon, Portugal
2019, p. 74). As presented by Martins, this frontier region became an important area of deforestation, modern-day slavery, and illegal mining. This example of interrelations between political and economic organizations is captured well by Michalowski and Kramer (2007, pp. 200, 209), who describe state-corporate crime as (a) state-initiated crimes when corporations contracted by the State initiate illegal activities toward the state interests or at least with its approval, and (b) state-facilitated corporate crimes when there are serious failures in the state regulatory structure for controlling corporate activities. Both are a direct collusion between public and private objectives.

As presented by White (2008), many green criminology investigations surpass the scientific debate of precaution and harm. That is, the ratification of international conventions and even agreement on risk assessment standards are political, rather than scientific, choices (White, 2008, p. 5; White, 2013, p. 28). At this point, it is still common to see politicians who do not support cleaner energy alternatives or waste management solutions, considering their costs as excessive, particularly for undeveloped countries, in spite 
of clear scientific evidence. From a scientific perspective, we know that the protection of an ecosystem is essential for preserving economic development since it will contribute to stable weather cycles and maintain the sustenance of local animal and human populations. Globally, many economic fora have supported alternative models of production as the only way to create a consistent development agenda, such as the 2030 Agenda, promoted by United Nations (UN), and the Platform for Accelerating the Circular Economy (PACE), created by World Economic Forum in 2018. Both of them try to align governments' and corporations' social, economic, and environmental interests, considering that sustainability must be a consensus.

The recent events in Brazil, such as forest fires and forced eviction of native people from their lands for the expansion of livestock and soy sectors have produced a worldwide concern, given the magnitude of the possible harmful effects. This scenario becomes even more threatening when national public authorities in Brazil, faced with the above-mentioned questions, choose to (a) discredit official data, researchers and universities, building anti-scientific narratives to legitimate the environmental public policies; (b) depreciate the importance of the Ministries of Environment and Human Rights, regulatory agencies and control instances by reducing budgets, withdrawing power, prerogatives and competence so that they won't carry out their functions and replacing their qualified leaders by supporters of government's environmental agenda; (c) publicly attack any external attempt of interference in their policies; and (d) revoke legitimate and proven environmental protection programs and rules that aren't in line with their purposes.

All those actions are also at the same time increasing illegal activities, such as illegal trafficking in gold, animals, and wood by armed groups in forest regions. As described by different Brazilian authors, the illegal activities, the land grabbing, the agribusiness growth, the biopiracy, and the violence in rural areas are all related in one continuum process of spoliation (Martins, 1993; Martins, 2019; Lencioni, 2012; Carvalho, 2013; Suaer\&Borras Jr., 2016). An important observation in this context is that at least seven Presidential decrees ${ }^{1}$ have relaxed the restrictions to guns' access, allowing different agents to buy more guns and ammunition, especially for "farmers" and "hunters". This flexibilization is interpreted by many Brazilian activists and researchers as direct support of existing militias (Peixoto, 2021). If we are right, the Brazilian situation goes beyond state-corporate

\footnotetext{
${ }^{1}$ Decreto n. 9.8442019 (PR) (DOE) (Bra), Decreto n.9.845 2019 (PR) (DOE) (Bra), Decreto n.9.846 2019 (PR) (DOE) (Bra), Decreto n.10.627 2021 (PR) (DOE) (Bra), Decreto n.10.628 2021 (PR) (DOE) (Bra), Decreto n.10.629 2021 (PR) (DOE) (Bra), Decreto n.10.630 2021 (PR) (DOE) (Bra).
}

crime, but rather we are talking about a State-Militia economic agenda endorsed by reckless individuals and organizations, promoting situations of "anomie" as already discussed by Bales (2012), when analyzing the gold exploration on Amazon.

The use of pesticides for agriculture has also been part of this bigger policy, supporting agribusiness. Between January 2019 and July 2021, 1,191 new substances were allowed to be produced and applied in Brazilian fields (Ministério da Agricultura, Pecuária e Abastecimento, 2021). Although very harmful, this is not the focus of this essay; instead, we focus on deforestation and the failures in environmental surveillance, including the speeches, the institutional disorganization, the lack of concern about violence against indigenous people, and the cancellation of enforcement instruments.

Thus, using an environmental justice approach, the essay argues that a violent process of accumulation by dispossession of native people and different biomes has been implemented in Brazil almost entirely by deregulation and public omission. This policy had created a lack of judicial liability, which means that no legal instruments are available to stop this agenda. We do not argue that in Brazil, the president and ministers are working directly for corporate interests, but rather they work in support of a bigger liberalization agenda, opposed to many international commitments and historical grass-root interest.

In this paper, we draw from White's (2008, p. 186) distinction between environmental promotion and environmental enforcement. The concept of environmental promotion includes communication, creation of environmental codes and audits, while the concept of environmental enforcement includes inspections, investigations, and the development of measures of compliance, judicial and extra-judicial instruments. Environmental enforcement should not be a "oneperson job", but a complex set of responsibilities and interdependent measures.

In order to support our position, this essay will present a discussion on four issues relevant to the environmental crisis in Brazil. First, we discuss federal government actions, including public discourses, political decisions, and omissions of control with regard to different Brazilian biomes resulting in damage to biodiversity, social harms, and economic loss. Second, we analyze the lack of representation of colonial origin States on political decision-making and its consequent impact on environmental inequality. Third, we focus on the judicial instruments available to challenge regulatory choices and their inability to hold organizations liable for an omissive environmental agenda. Finally, we speculate about the lack of international liability for an omissive environmental agenda. The first section uses a journalist review, considering the official narratives-which is important to comprehend the public message created by the federal government. Sections two and three present a systematic 
review, demonstrating how the Brazilian net of environmental enforcement has been disabled on purpose. The fourth part draws from literature on international criminal law and its possibilities.

\section{Brazilian's Current Situation in Terms of Environmental and Humanitarian Damages}

Brazil has experienced three main environmental crises in the last three years, besides the Covid-19 pandemic. To be able to better understand the environmental public agenda and its particularities, it is important to take a better look into the nature of these occurrences and the public response to them.

According to official data gathered between 2007 and 2014, Brazil had a considerable decrease in Amazon deforestation in that period, almost $82 \%$ less. Deforestation started to rise again, particularly between 2015 and 2016, by about $22 \%$. In 2019, Brazil registered 163,219 fire spots, $44 \%$ above the same period in 2018. Only in the Amazon region, there were 72,461 detected occurrences, $29 \%$ higher than the episodes of 2018 (Instituto Nacional de Pesquisas Espaciais, 2019). Even though no one can define the exact amount of economic and social impact, it is generally understood that the Amazon deforestation might result in (a) continuous decrease of opportunity for sustainable use of the region, including significant losses in agriculture; (b) damage to biodiversity, much of which is still estimated to be unknown; (c) damage to socio-diversity, especially to indigenous people and traditional extractive populations such as rubber tappers, creating new environmental refugees; (d) impacts on the hydrologic cycle, as the Amazon winds are crucial in carrying evaporated water from the Atlantic Ocean, which, coupled with its own evapotranspiration, brings recycled water to the Andean region and even to south-central territories of Brazil; (e) increase in carbon dioxide emissions, since the deforestation itself produces $\mathrm{CO} 2$ and other gases, some of them not absorbed by secondary forests, such as $\mathrm{CH} 4$ e N2O; and even (f) energy crises and river transportation damages (Fearnside, 2006; Malheiro et al., 2021). In simple words, many different environments, species, and populations have been directly affected by the events that have been destroying the Amazon Rainforest.

According to the report of the Indigenous Missionary Council (CIMI), violence against native peoples has become an institutional policy, as the government tends to prioritize patrimonial and economic interests over the environment and human dignity of those peoples. There are constant invasions of indigenous territories, even of those that have already been demarcated and recognized by the federal government a long time ago. Most of the time, those invasions happen to meet the interests of loggers, land grabbers, miners, prospectors, and landowners. ${ }^{2}$ These trends tend to be aggravated when there is a governmental alignment with the private entities of these sectors, through the establishment of policies to deregulate the norms concerning the environment and native people (PALOSCHI, 2019, pp. 9-10).

It should be noted that, in 2018, 111 cases of land invasions, illegal exploitation of natural resources, and patrimonial damages to indigenous territories were registered, 99 of them in the areas of the "Legal Amazon" (Conselho Indígena Missionário (CIMI), 2019, p. 56). In 2019, with a rise in Amazon deforestation, indigenous people's environment was severely damaged and conflicts motivated by land disputes increased in the same proportion, causing the murder of many indigenous leaders. In 2020, the shortage of medical services became a major concern due to the Covid19 outbreak. The Federal Government decided to delegate all the responsibility to the governors and municipal majors and did not contribute to any national plan. ${ }^{3}$

The second environmental crisis started in August 2019, when oil slicks spread along the extensive northeast coast of Brazil. Notified of the incident that affected many beaches of different states, the Ministry of Environment did not use any of its instruments to deal with the incident, as the official contingency plan foresaw on Decreto $n$. 8.1272013 (PR) (DOE) (Bra). Moved by despair, worried about economic loss owing to a decrease in tourism, volunteers started to clean the beach sand themselves. At least 66 volunteers in the state of Pernambuco were contaminated by dealing with the oil without proper equipment $(\mathrm{G1}, 2020)$. The main public speech made by Environment Minister Ricardo Salles was on social media during Greenpeace's manifestation. Salles accused protesters of using violence instead of helping to clean the oil-stained Brazilian coast, calling them "eco-terrorists". Greenpeace sued the Minister for calumny, but the Federal Prosecution considered that Salles had only used his "right of free speech". The charge was dismissed

\footnotetext{
${ }^{2}$ Recently, two attacks were noticed by the Conselho Indígena Missionário: (a) the attacks of prospector against Yanomami communities in Roraima state on May (Conselho Indigena Missionário (CIMI), 2021a, 2021b) the drowning of two indigenous kids by an illegal water bomb installed by gold prospectors (Conselho Indigena Missionário (CIMI), 2021c). We consider that those actions are a direct reflex of Federal Government omission on environmental enforcement. According to the Comissão Pastoral da Terra (2021, p. 8) statistics, there were 20.000 illegal prospectors working on these Yanomami lands in Roraima state.

${ }^{3}$ During the pandemic, the Government had three different Ministers of Health, who prioritized the creation of misinformation. Even the official numbers started to be audited by a media consortium, because of the lack of transparency on federal reports. With the arrival of vaccines, no federal campaign was presented and priority groups were not well defined, with each state creating its own priorities for those few doses available. See: Homero, 2020; Folha de São Paulo, 2021.
} 
on November 30th, 2020 (case Greenpeace Brasil v. Ricardo Salles).

At least 130 cities in 11 states had been affected. The Navy and the Federal Police initiated two separate confidential investigations. Since then, no charge has been presented and no data published. The only suggestion about the origin of the oil leak was made by the Brazilian President, who decided to accuse the Government of Venezuela of the environmental crime, although no proof was shown or confirmed.

During the year 2020, another important biome, the Brazilian "Pantanal", located in the states of Mato Grosso and Mato Grosso do Sul, suffered severe damages. In the first half of the year, that region experienced $158 \%$ more fire outbreaks than in the same period in 2019 (Fundação de Amparo à Pesquisa do Estado de São Paulo, 2020). By the end of the year, no practical measure was taken by Federal Government. September was the worst month ever recorded by INPE, with 8,106 fire spots (Instituto Nacional de Pesquisas Espaciais, 2021a). At the end of the year, 13.9\% $\left(20.833 \mathrm{~km}^{2}\right)$ of "Pantanal" had been burnt, which meant the worst score since 2005 (Instituto Nacional de Pesquisas Espaciais, 2021b). There were many reports of animals invading cities, trying to escape from the flames. The fires also affected small livestock producers and indigenous communities in the state of Mato Grosso do Sul. ${ }^{4}$

\section{Governmental Policies and Discourses on Environmental Matters in Brazil}

The concept of 'environment' includes different natural, social, economic, and political aspects, which means that every environmental policy must also include different perspectives. As demonstrated by Antonio Carlos Diegues (2008, p. 17), there is a modern myth that refers to protected natural areas as places that should be totally isolated from humans to keep their preservation. It implies that the only way for us to develop and survive is through environmental destruction. This limited idea of modernity and development has created much damage to traditional cultures and indigenous people, who have already developed a more harmonious relationship with nature and also depend on it for survival. ${ }^{5}$ Because of this, many modern environmental standards are economic and socially disproportionate and harmful at the same time.

\footnotetext{
${ }^{4}$ As presented by CIMI, the community Guarani Kaiowá, in the state of Mato Grosso do Sul suffered multiples attacks in 2021, including the burning of their houses by private securities (Conselho Indígena Missionário, 2021b).

5 As demonstrated by the author, many conservationist policies also imply the expropriation to preserve a sanctuary of "wildness" (Diegues, 2008, p. $21 \&$ ff.).
}

In this context, the "environmental justice" debate introduces a new concept of "sustainability" (Whyte, 2016, p. 189), rearranging elements such as technological innovation and human behavior, as well as a different concept of justice, beyond distributional equality - they demand the recognition of their legitimacy to decide their interests (Schlosberg, 2004, p. 522). As pointed out by Stella M. Čapek (1993, pp. 5-8), "Environmental Justice" is a whole new framework, that demands special attention for victims and local groups. But, beyond its origins in the civil rights rhetoric, it also started to highlight how political decisions are deeply harmful to minorities and different cultures who are not heard. ${ }^{6}$

In a certain way, left-wing governments in Latin America brought those traditional perspectives and values (e.g., buen-vivir) to a new model of economy, trying to create value without deforestation, exploring new products as fruits, natural oils and, nuts (as an example, the açaí fruit and palm, see Weistein \& Moegenburg, 2004). These "newextractivism" businesses, as called by Vergara-Camus and Kay (2018, p. 352), were not successful to guarantee food sovereignty, but at least brought an opportunity to cooperate between communities and public institutions, revealing potentialities of sustainable investments, without any reduction in agribusiness, which has experienced a great decade due to exports of soy, steel, and meat to China.

However, since his presidential campaign in 2018, the Brazilian president has determined that those dual policies are not enough to support agribusiness, which, in his view, needs more and more land to increase production without investment in technology or resources. Government policies became remarkably simple: (a) no more land for indigenous people (which means fewer opportunities and resources for them); (b) no more public incentives for small businesses (no credit to invest and abolition of many programs that used to offer technological support to insert new products on market); (c) no more protection to communities (disengagement and shutdown of public institutions on health, education, food sovereignty, and security). Illegal deforestation started to grow again, as it did in the past decades, despite global agreements and economic barriers to products that originated from it. Violence against those traditional groups

\footnotetext{
${ }^{6}$ Kyle Powys Whyte (2016, p. 182) presents a special reference to an episode in Uluru-Kata Tjuta National Park, in Australia, where visitors needed different permits to have access to the Park, but they were exempt from following a Tjukurpa law, which forbids anyone to climb sacred places. There are many other examples as to how the lack of communitarian participation might become harmful, not only by symbolic aspects.
} 
and deaths have also increased (Comissão Pastoral da Terra, 2021). ${ }^{7}$

It is important to know that the country's political scenario has changed radically in the last six years, but not so much with regard to the economy, which still is based on the primary sector, especially minerals, agriculture, and livestock. During the 2018 presidential election, the political protagonists of these economic sectors decided to support Jair Bolsonaro with three main proposals: (1) fight left-wing politicians, parties, and thinkers; (2) rebuild Brazilian economic plan and rules; and (3) expand firearms license to citizens, especially to farmers.

This alliance and political agenda are related to the Amazon crisis. In the fight against leftist politicians, parties, and thinkers and in his ideas about reconstruction of Brazilian economic plan and rules, the elected president has spoken out against environmental activists and indigenous people, among others who are against the political agenda he wants to set in motion. During the campaign, the Brazilian president made statements about: (a) the necessity of eliminating the Ministry of Environment, transferring its competencies to the Ministry of Agriculture (Bragança, 2018); (b) his position of not granting land to the indigenous people, to keep it with the farmers (Resende, 2018); (c) the support to the United States withdrawal from Paris Agreement, promising that Brazil would do the same; and d) the promise to reduce bureaucracy for environmental licenses.

Once elected, the President of Brazil could not carry out his intentions completely: (a) fearing international retaliation to Brazilian rural products, he went back on his proposal to eliminate the Ministry of Environment, but still transferred some environmental roles to the Ministry of Agriculture, mainly the regulation and creation of new indigenous reserves (Phillips, 2019); and, (b) in exchange for the support of France to Mercosul and European Union commercial agreement, he promised to keep the commitment to the Paris Agreement, but not without diplomatic problems with the French and German governments.

The Brazilian President usually declares that international discussions on Amazon-related questions without the participation of the presidents of the countries involved reflect a misplaced colonialist mentality in the twenty-first century. Regarding the indigenous issue, he accused some indigenous leaders of being used as "switch gears" by some international governments with interests in the region. This attitude could be seen on the eve of the G7 summit and in the opening speech at the General Assembly of the United

\footnotetext{
7 According to the Comissão Pastoral da Terra (2021, p.7), 2020 became the year with the highest number of rural conflicts in Brazil since 1985 (when the CPT started their statistics). This number is 25\% higher than 2019, 57,6 higher than 2018.
}

Nations that took place in September 2019. These facts have shown that the Brazilian government's most common discourse is that the Amazon issue is a national problem, ${ }^{8}$ and no foreign organization could interfere with it because it would be an attack on Brazilian sovereignty (G1, 2019; BBC News, 2019).

In the matter related to the idea of expanding firearms licenses to citizens, especially farmers, the main goal is to facilitate their defense in confrontation with indigenous people and protestors pro land reform. This is a very problematic issue in the Amazonian area because many of these producers are in constant conflict with indigenous populations, even invading their reserved areas, making the environmental and humanitarian situations even worse in the region.

At the same time, a new management model was implemented in the public health system, reducing investments in the indigenous special sector. In 2019 they received almost $25 \%$ less money than in the previous year, in addition to having their popular councils eliminated and medical care decreased since the Cuban doctors departed from the region after Bolsonaro started a diplomatic offensive against the Cuban government (Junqueira, 2019).

Destruction of the indigenous areas, plus the absence of guarantees of land demarcations for indigenous people, firearm power given to the farmers that invade indigenous land, and the change in the indigenous public health system are the main reason why the indigenous leadership is now accusing the Brazilian president of "genocide" against those populations.

In addition to the just describe political scenario, it is important to check its administrative consequences. The Brazilian Ministry of Environment has different political councils, technical departments, and associated agencies. The Brazilian Institution of Environment and Renewable Resources (IBAMA) is the most important of them, responsible for granting licenses to explore forest resources and supervising the national forest fire prevention system (the Sisfogo), among other functions. Since the beginning of 2019, the Brazilian government has adopted several measures that weakened the institution. From the beginning of the presidential election campaign, Bolsonaro has promised he would put an end to what he called "IBAMA fines industry" (Seto, 2018; Watanabe, 2018), which, in his opinion, only disturbs Brazilian businesspeople and farmers (Betim, 2019). The President himself was once fined in 2012, when he was still a congressman, for illegal fishing in a protected area, but, after his election, the fine was withdrawn and the

\footnotetext{
$\overline{8}$ Bolsonaro and his selected Minister of Agriculture and Minister of Foreign Affairs denied the existence of an anthropogenic climate change, which they consider to be an "invention of Marxist ideology". See at: Fearnside, 2018, p. 360; Ferrante \& Fearnside, 2019, p. 2 .
} 
inspector responsible for it was dismissed (Tavares \& Maisonnave, 2019). This was not the only case of personnel changes in the institute. On February, 21 of the 27 Regional Representatives of IBAMA were dismissed (Folha de S. Paulo, 2019).

This framework was reflected in the data obtained in 2019, which show that, despite the exponential increase of fire spots in the Amazon that year, the number of fines applied to environmental infractions decreased. There were 72.800 fires registered in August 2019, 83\% more than in the same period in 2018; meanwhile, there was a $29.4 \%$ drop in the number of assessments. Considering only the violations against flora (i.e., illegal destruction or extraction of plants, wood, and herbs), the reduction is $38.7 \%$ in the whole country and $42.4 \%$ in the legal Amazon (Shalders, 2019).

Although the lack of resources to fight against deforestation has been a constant argument used by the government, the available budget has been reduced by actions by same government. In May, after pointing out alleged irregularities in the international "Amazon Fund", the government tried to change its destination, which would no longer be to IBAMA, but to compensation of farmers. This situation led donor countries, such as Germany and Norway, to fully cut the grant, considering that Brazilian environmental policies were no longer trustworthy (Amaral, 2019).

To support these policies and keep public opinion on its side, the federal government took a clear position by discrediting scientific data (Girardi, 2019), deflecting any responsibility by using false claims of "communism threat" and "ideological speeches on the environment", using the same well known imported conservative rhetoric used during the military regime in Brazil. In August 2019, the Head of INPE was dismissed, after being accused of damaging the image of Brazil abroad and "be serving a certain NGO" (Londoño, 2019; Fórum, 2019). ${ }^{9}$ Different researchers also have reported having been supervised in scientific events by government agents, while presenting criticism on the Federal policies.

In April 2020, during an official meeting between the President, his Ministers, and other important figures of the government, Environment Minister Ricardo Salles proposed that different offices should join together to seize the opportunity "given" by Covid-19. For him, the president should deregulate activities and "pass the cattle" ("passar a boiada", in Portuguese) while everyone's attention was focused on the pandemic. The video of the meeting became public after

\footnotetext{
9 It is interesting to observe that, in an interview to BBC Brazil, Douglas Morton, Head of NASA Biosphere Sciences Laboratory, classified the dismissal of Ricardo Galvão as "alarming", since it reflects the way Brazilian Government deals with sciences. See at: Barrucho, 2019
}

a judicial claim from a whistleblower, but no intervention was made.

During 2020, a large deregulation process was implemented: (a) the revocation of the Resolução n. 2842001 (CONAMA) (DOE) (Bra), which regulates the license to use irrigation; Resolução n. 3022002 (CONAMA) (DOE) (Bra) and Resolução n. 3032002 (CONAMA) (DOE) (Bra), which regulate protected areas ${ }^{10}$ (specially the coastline forests, like mangroves and sandbank vegetation); (b) the revocation of 305 decrees at once (Decreto n. 10.4732020 (PR) (DOE) (Bra)), mixing distinct subjects, like environmental programs and administration holidays, just to confuse and hinder public control (information overload) ${ }^{11}$; (c) in March, the Head of IBAMA simplified the surveillance of wood exports, using only self-declarations for records (but, this instruction was not published and it was only announced in November 2020) (Estado de Minas, 2020); (d) in April, the instruments of surveillance for environmental licenses were restricted due to Covid-19 pandemic by the Comunicado $n$. 73376712020 (GABIN) (DOE) (Bra) ${ }^{12}$; (e) regularization of illegal owners was facilitated by the municipalization of land registration, allowing invaders to take protected areas by the Instrução Normativa n.104 2021 (MAPA) (INCRA) (DOE) (Bra); (f) again, the budget for the Ministry of Environment is smaller in 2021, the smallest one since 2000 (Girardi, 2021), which means that there is no intention to reinforce surveillance mechanisms.

\section{National Legal Instruments}

In view of the absence of corrective measures of control by the government to avoid damage to the Amazon rainforest, it is important to consider the role of law to face the environmental crisis. Currently, there are five main legal procedures in Brazil that could help in the environmental and indigenous causes.

First, the most ordinary legal resource to deal with environmental problems is the civil action in the public interest—ação civil pública -, lawsuit in defense of public or social goods proposed by the public prosecution. It is based on the classic idea of civil responsibility: whoever

\footnotetext{
${ }^{10}$ All three revocations were suspended by three lawsuits: (a) ADPF 747 STF, Plenário, DJE n.71, 2021; ADPF 748 STF, Plenário, DJE n.289, 2020; ADPF 749 STF, Plenário, DJE n.289, 2020.

11 As examples of important programs extinguished: (a) Decreto de 26 de setembro de 1997, to support the irrigation for fruit production in the Northeastern Brazilian states; (b) Decreto de 20 de agosto de 2004, that created a commission for gender and race equality; (c) Decreto $n$. 8.736/2016, the national program for rural youth.

12 This flexibilization was revoked on December 1st, 2020 (Comunicado n. 87536132020 (GABIN)), based on "Covid-19 slowdown".
} 
has caused the damage will be liable for it. The difference here is that this peculiar civil action is used to deal with non-individual rights and the damages are usually hard to be delimited. In Brazil, the damages caused to the environment are judged in a specific public tort lawsuit, provided by Lei n. 7.3471985 (Cn) (DOE) (Bra). It may be also proposed by many other governmental bureaus, like IBAMA, with the specific intent to implement fines, monetary compensations, different reparations, and even covenant clauses.

From a preventive perspective, Brazilian authorities might bargain through a "conduct amendment agreement"- termo de ajustamento de conduta. Using this instrument before the damage is established and the lawsuit is being conducted, any of the authorities allowed to start a civil action in the public interest can propose and make a deal about the corporation productive system or even come to an agreement about how it should repair social, financial, or environmental damages, reducing their tort liability.

The official misconduct lawsuit—ação de improbidade administrativa -, provided by Lei n. 8.4291992 (Cn) (DOE) (Bra), has a very specific system with a hybrid nature between administrative, civil, and criminal law. In this case, any public agent may be sued for misconduct (action or omission) provided by the law, with no restrictions to the punishment of the crimes that are correlated to this particular misconduct.

The "noncompliance with fundamental commandment lawsuit"- arguição de descumprimento de preceito fundamental (ADPF)-, provided by Lei n. 9.8821999 (Cn) (DOE) (Bra), has a preventive effect against any kind of rule that may be opposed to constitutional principles. The ADPF became fundamental against the serious regulation reversal proposed by Minister Salles.

In terms of sanctions, the offender may be responsible for civil repair to damage caused to public finances and/ or for diffused damages, with an administrative penalty, in general, and criminal liability. The punishment of crimes related to these misconducts may be reinforced with sanctions, such as the prohibition of access to other public functions. This law can be applied to environmental misconduct mainly when the public authority conduct (action or omission) determines the necessity of state intervention to repair the damage, meaning some sort of financial damage, or if the conduct is notoriously against the law or with the aim of achieving a forbidden goal.

Finally, there is the Lei $n$. 9.6051998 (Cn) (DOE) (Bra), which typifies most of the environmental crimes in Brazil, forbidding many acts against the environment, including forest fire. Any person or legal entity could be made liable, with the possibility of an organization being convicted without any individual responsibility. Even legal entities of public administration ${ }^{13}$ (not only State business) may be subject to criminal liability.
It must be highlighted that Lei 9.6051998 (Cn) (DOE) (Bra) has its own penalty system. In Article 6 provisions, three elements are relevant to determine culpability: (1) damage gravity and its consequences to public health; (2) precedent environmental misconduct; (3) infringer's economic capacity, in case of fine. In accordance with Article 8 , prison may be replaced by (a) community services; (b) temporary disqualification (as licenses and political rights); (c) total or partial suspension of economic activities; (d) pecuniary penalties; (e) home detention. Finally, in Article 14 , it is provided that different post-facto actions may reduce future penalties, such as prior communication to authorities about environment degradation and cooperation with environment personnel.

One vulnerability of this system lays in the fact that it does not distinguish penalties applied to individuals from the ones applied to organizations. Brazilian law does not have enough criteria to punish companies and, what is even worse, does not have any better choices to offer than administrative law penalties. It is urgent to find more adequate solutions, mainly to major disaster events (like those that occurred in Mariana ${ }^{14}$ and Brumadinho ${ }^{15}$ recently). ${ }^{16}$ Regarding forest fires, as an example, there should be special preventive cooperation duties among farmers living near damaged areas, which would compensate for the lack of information about the starts of fires. In other words, the number of vigilant gatekeepers should be increased, rather than concentrating efforts on the difficult search for fire-causing agents.

The main issue here is that the legal instruments listed above present two problems in common: (a) enforcement problems, due to agencies" "capture" or shortage of equipment, lack of human resources and public engagement, and,

\footnotetext{
13 See: Prefeitura de Florianópolis v. Ministério Público Federal. (2014). TRF-4. Quarta Turma. Proc.n.0000574-90.2009.404.7200 (Bra).

${ }^{14}$ On November 5th, 2015, at approximately 3:30 pm, the so-called "Barragem de Fundão", located in Mariana (State of Minas Gerais) broke, causing the immediate overflow of about 40 million cubic meters of iron ore and silica tailings, and another 16 million cubic meters that continued to flow slowly. This tragedy has caused environmental, economic, and social damage, including the death of 19 people. Check with details in Prata, 2019, pp. 37-75.

15 On January 25th, 2019, the so-called "Barragem 1 da Mina do Córrego do Feijão”, located in Brumadinho (State of Minas Gerais) collapsed, causing the death of at least 259 people (still undercounting), destroying villages, and causing inestimable environmental damage. See with details in: Feliciano \& Pasqualeto, 2019, p. 12 \& Ss.; Busato, 2019, p. 7.

16 This observation is important to demonstrate how the Brazilian academy has not developed the dialog needed with the criminal justice system, creating a scientific stagnation that is not able to answer real problems properly. This is not about President Bolsonaro, but how particularly unprepared our judicial system has been to different environmental struggles. The institutes are all presented, but their use is still immature and notably limited.
} 
presently, absence of political legitimacy ${ }^{17}$; and (b) difficulties in establishing the correlation between public policies and environmental disasters. The second problem is worsened because of a lack of proof and is also affected by the first one. These two problems are not only local but also a serious national example of a lack of enforcement in environmental issues.

As highlighted by Rafael Boldt (2021, p. 103), the Brazilian case is a clear example of the reluctance of governments and companies to assume responsibility for environmental protection, including a strong corporate pressure on the governments so that their economic interests may not be affected by environmental issues. Penalties and financial compensation are often so low that the offending corporation prefers to be condemned on these practices, rather than implement preventive ones.

In this respect, Dias and Budó (2019, pp. 294-295) and Natali (2014, p. 9) highlight how environmental damage is largely caused within the legislation, having in the State itself one of the greatest harm perpetrators, undermining already fragile protective instruments. ${ }^{18}$ Even the denialist discourse-widely observed in Brazilian politics—has long been denounced by criminology, which observed on it some neutralization techniques that try to legitimize actions by denying the existence of damages, victims, responsibilities or even claiming that its actions were practiced for the common welfare (Dias \& Budó, 2019, p. 295; White \& South, 2013, p. 29).

Eduardo Saad-Diniz (2020) also asserts that the Brazilian criminal justice system lacks legal instruments for corporate social control, which increases the risk of other environmental disasters, before presenting compelling responses to those already experienced. In addition, it is noteworthy to say that the corporate lobby is able to "capture" legislative choices and popular representation, weakening confidence in the rule of law (Saad-Diniz, 2019b, p. 140). This remains clear in the Brazilian case, where political choices, as noted, do not necessarily serve the common welfare, but the interests of specific economic groups, instead.

A clear example of the Brazilian deficiency in terms of poor regulation, disjointed enforcement strategies, and corporate resistance to cooperating is also brought by SaadDiniz (2019a, p. 9), who reminds us that even after a tragedy of the magnitude of the dam break in Mariana, the attribution of corporate and individual responsibility remains a blank page. In addition, Samarco (the company involved in the disaster) remains a leading company in corporate social

\footnotetext{
17 See with details: Agapito et al., (2019).

18 On "green criminology", see: Armendariz Ochoa, 2020, pp. 114115.
}

responsibility, having even received ISO 14001 certification in 1998.

In terms of a particular answer, Brazilian prosecutors, with their large legal prerogatives, could enforce administrative sanctions and even encourage deep compliance programs by means of soft law attributions. Whereas different regulatory agencies are vulnerable to politics, Brazilian prosecutors have administrative autonomy, financial independence, and personal stability to act without interference or pressure. Even so, the future of active involvement of Brazilian prosecutors in environmental protection enforcement does not look promising, because of (a) the lack of special knowledge about scientific environment issues, (b) the much larger amount of resources available to companies compared to public agencies, and (c) the absence of institutional engagement (Agapito; Miranda; Januário, 2019). Therefore, in our view, it would be helpful to pursue international enforcement standards with soft law instruments to reinforce the local environmental law, especially since economic incentives may be part of such international enforcement.

\section{International Criminal Law as an Answer}

Since the national legal system apparently cannot give an adequate answer to Brazilian environmental issues, appealing to international criminal law would be a feasible solution. As stated by Rosario de Vicente Martínez (2018, p. 251), environmental damages have the general characteristics of crimes against the peace and security of mankind, which would make the provision of an environmental international crime possible. This is the reason why the International Association of Penal Law-AIDP_in 1994 approved at the 15th International Congress of Penal Law, held in Rio de Janeiro, Resolution 23, which determines that "core crimes against the environment affecting more than one national jurisdiction or affecting the global commons outside any national jurisdiction should be recognized as international crimes under multilateral conventions" (Association Internationale de Droit Pénal, 2015, p. 373).

Global awareness of the potential need for intervention by supranational spheres of criminal law to deal with environmental damage is linked to the serious events that occurred in times of armed conflicts, especially the use of "Agent Orange" in the Vietnam War and oil spills in the Gulf War. Those were some of the reasons why environmental damages were included in the Rome Statute, Art. 8.2, "b", "iv", among the War Crimes, in these terms:

"(iv) Intentionally launching an attack in the knowledge that such attack will cause incidental loss of life or injury to civilians or damage to civilian objects 
or widespread, long-term and severe damage to the natural environment which would be clearly excessive in relation to the concrete and direct overall military advantage anticipated."

Even though there is "long-term and severe damage to the natural environment," the Brazilian context of this environmental damage would hardly be recognized by law professionals as an armed conflict, in addition to many reservations expressed by Brazilian sociologists (Martins, 1993, p. 144). Therefore, the application of this article to the Brazilian case is impossible. We would like to speculate about the possibilities of intervention of international criminal law in the Brazilian context, where-we would argue-economic actors of predatory capitalism supported by the government are in conflict with indigenous and environmental protection rules, implementing their own terms on environmental management.

The indigenous leaderships' accusations of genocide could be analyzed through the provision of Art. 6 of the Statute, regarding genocide crimes. However, the article clearly states the need for an "intent to destroy, in whole or in part, a national, ethnical, racial or religious group". Proof of this volitional element, if it is considered present in the Brazilian case, would be extremely difficult and circumstantial, being hard to demonstrate that the actions and discourses of the Government were deliberate to destroy the indigenous populations and their environment. ${ }^{19}$ In fact, it is important to highlight how some criminologists have long denounced how the idea of "intentionality" behind crimes turns out to be a factor of evasion of responsibilities by large companies and states, ignoring the fact that many times an abstention from action and indifference are potentially more damaging (Dias \& Budó, 2019, p. 10; Hyllard \& Tombs, 2013, p. 180).

In the particular case of American countries, the jurisprudence in this matter is still incipient and restricted to a few indigenous cases of armed attacks and land dispossession, even though the American Convention on Human Rights is clear about the right to progressive development in its Art. 26, and also, the Protocol of San Salvador (1988), in its Art. 11, is even more precise about the right to a healthy environment ${ }^{20}$ :

"Right to a Healthy Environment. 1. Everyone shall have the right to live in a healthy environment and to have access to basic public services. 2. The States

\footnotetext{
19 On the difficulties of analyzing environmental damage in light of existing international crimes, see in detail at: Sieders, 2020, pp. 34-36.

20 As an example, see the Case of the Plan de Sánchez Massacre $v$. Guatemala (2004). As we can see from Sect. 49 (VII Proven facts), the State was suited for interference on indigenous rituals, controlling activities by surveillance and military ostensibly presence.
}

Parties shall promote the protection, preservation, and improvement of the environment"

As explained by Mariane Stival (2018, p. 41; 44; 47 \& ff.), the environment until now is not debated as an autonomous area of concern by the Court, which tends to connect this issue to the protection of other rights, such as life, health, and property. This gap in supranational criminal law makes the debate about the inclusion of "ecocide" as the $5^{\text {th }}$ international crime gain momentum. As argued by Rosario de Vicente Martínez (2018, p. 261), it can be defined as the destruction of our natural environment, precisely as the damage or destruction of the ecosystem from a particular territory.

The Office of the Prosecutor from the International Criminal Court published in 2016 the "policy paper on case selection and prioritization", in which it was written that the Office would seek to cooperate and provide assistance to the States, with respect to, among other crimes, illegal exploitation of natural resources. Beyond that, it was defined that special attention would be given to crimes committed by means of, or that result in, "the destruction of environment, the illegal exploitation of natural resources or the illegal dispossession of land" (Office of the Prosecutor, 2016). ${ }^{21}$

This topic, although not so new, still depends on more detailed studies and discussions. As observed by Rafael Boldt (2020, p. 20), there are some doubts about whether the creation of new criminal types is the most adequate solution to face the environmental crisis. Beyond that, the mere inclusion of "ecocide" in the catalog of international crimes may not be enough if not able to affect both corporations and heads of government. However, there is an undeniable reluctance of the latter in assuming an environmentalist agenda, precisely because of the pressures from large corporations aiming to protect their financial interests. ${ }^{22}$

Specifically, in the Brazilian case, the government has also raised questions about the violation of its sovereignty by international attempts to confront the problem. In fact, it seems to us that it is a Brazilian right to economically exploit the Amazonian region. However, what is the boundary between this legitimate right and abuse assuming international proportions? This is a topic that must be analyzed very carefully, separating the cases involving a systematic or general attack threatening global security-which will be under the International Criminal Court jurisdiction- from the ones that should be processed and judged by the national courts.

\footnotetext{
${ }^{21}$ See, with details: Altoé \& Santos, 2018, pp. 428-431.

22 Also about the consequences of the inclusion of ecocide as the 5 th international crime: Hellman, 2014, pp. 278-280).
} 
Therefore, although the future inclusion of ecocide as an international crime seems very promising, there is still a relatively long way to go before this issue can be faced with the seriousness it demands. However, the environmental issue is undeniably urgent, a fact that became even clearer in 2019 as we explained earlier. For this reason, in parallel to this future inclusion, it is very important that more immediate measures are considered, especially in terms of policies to encourage sustainable economic initiatives and innovation to promote regulatory integration and civil society participation. The new international crime proposed here has to be "on the top of the regulatory pyramid" (where the base is certainly local regulation) in countries where environmental and humanitarian issues are in conflict with economic power.

\section{Conclusions}

Brazil has a fundamental role in terms of preventing environmental damage, the reason why its predatory government policies, which have been clearly evident since 2019 , have worried the international community, fearing their effects on a global scale. Unfortunately, the Brazilian government, which should be primarily responsible for adopting preventive and repressive measures related to environmental issues, is closely aligned with the interests of large corporations, rural producers, and the extractive sector, but particularly by their illegal relationships with prospectors. To safeguard their own narrative, the Federal Government has been hostile to the scientific community and to the press, the main sectors interested in warning the population about the seriousness of the situation.

Besides that, the Brazilian internal preventive-regulatory framework lacks input from important affected segments of the population. As we have tried to demonstrate in this essay, the Brazilian environmental injustice scenario reveals how colonial political institutions and enforcement agencies remain in charge of decision-making nowadays. Without the satisfactory representation of affected communities, public interest will be captured by corporate agendas and even militia interests. This loophole has also been instrumental in disabling judicial instances and autonomous agencies, such as federal prosecutors. In other words, Brazil experiences an undeniable fractal repetition of failure in enforcement related to environmental harm and damages.

As seen in this report, it is crucial to move forward with discussions related to environmental impacts in the sphere of international criminal law and the lack of liability for harmful agendas. In particular, evidence of a volitional element ("intent to destroy, in whole or in part, a national, ethnical, racial or religious group") on the part of the government is a very complex matter. Therefore, because of the seriousness of the Brazilian environmental situation-which became evident in 2019-and the extent of its possible damages on a global scale, it seems imperative and urgent to address the issue in the international sphere, to guarantee access to justice for affected communities and to interrupt the illegal activities in the region.

Funding Not applicable.

Data Availability Not applicable.

Code Availability Not applicable.

\section{Declarations}

Conflict of interest All Authors declare that they have no competing interest.

Ethical Approval Not applicable.

Consent to Participate Not applicable.

Consent for Publication Not applicable.

\section{References}

Additional Protocol to the American Convention on Human Rights in the area of economic, social and cultural rights: "Protocol of San Salvador". (1988). Retrieved 6 February 2020 from https://www. oas.org/juridico/english/treaties/a-52.html.

ADPF 748 STF, Plenário, DJE n.289, 2020.

ADPF 749 STF, Plenário, DJE n.289, 2020.

ADPF 747 STF, Plenário, DJE n.71, 2021.

Agapito, L. S., Miranda, M. A. \& Januário, T. F. X. (2019). A ganância econômica e os crimes ambientais: a sustentabilidade como parâmetro para o risco permitido no direito penal ambiental. In F. Figueroa, E. Saad-Diniz, M. Parra, A. Trindade \& Kleiman, H. (Eds.), RIDP libri 04: Alternativas al sistema de justicia criminal latinoamericano: V Simpósio de Jóvenes Penalistas de la Asociación Internacional de Derecho Penal (pp. 304-323). Maklu.

Altoé, R. \& Santos, M. F. (2018). Tutela penal do ecocídio e a Lei n. 9.605/98: um novo horizonte após a recente manifestação do Tribunal Penal Internacional. In É. M. Carvalho \& Prado, A. M. (Orgs.), Repensando a proteção do meio ambiente: 20 anos da Lei 9.605/98 (pp. 417-434). D’Plácido.

Amaral, A. C. (2019, August 26). Decisões da gestão Bolsonaro fragilizam controle ambiental. Folha de S. Paulo. Retrieved October 21, 2019 from https://www1.folha.uol.com.br/ambiente/2019/ 08/decisoes-da-gestao-bolsonaro-fragilizam-controle-ambie ntal.shtml.

Armendariz Ochoa, L. F. (2020). Looking for an effective environmental protection: Contributions from green criminology and economic criminal law. RIDP, 91(1).

Association Internationale De Droit Pénal (2015). Revue Internationale de Droit Penal: Résolutions des Congrès de L'Association Internationale de Droit Pénal (1926-2014), 86ª année nouvelle série - 1er/2o trimestres 2015. Retrieved May 23, 2021 from http://www.penal.org/fr/r\%C3\%A9solutions-des-congr\%C3\% A8s-aidp-iapl.

Bales, K. (2012). Disposable people: New slavery in the global economy. Revised edition. University of California Press. 
Barrucho, L. (2019, August 7). Demissão de chefe do Inpe é 'alarmante', diz diretor de centro da Nasa. BBC News Brasil. Retrieved October 28, 2019. https://www.bbc.com/portuguese/ brasil-49256294.

BBC News. (2019, August 26).De Amazônia a ofensa a esposa, as frases da escalada de tensão entre Bolsonaro e Macron. Retrieved May 23, 2021 from https://noticias.uol.com.br/ultimas-noticias/ bbc/2019/08/26/de-amazonia-a-ofensa-a-esposa-as-frases-daescalada-de-tensao-entre-bolsonaro-e-macron.htm.

Betim, F. (2019, May 8). Bolsonaro neutraliza o papel do Ibama na aplicação de multas ambientais. El País. Retrieved October 31, 2019 from https://brasil.elpais.com/brasil/2019/04/11/politica/ 1555009346_229285.html.

Boldt, R. (2020). Ecocídio, crime contra a humanidade?. Boletim IBCCRIM, 27 (236).

Boldt, R. (2021). Ecocídio e responsabilidade empresarial nos crimes ambientais. Revista Brasileira De Ciências Criminais, 29(175), 91-111.

Bragança, D. (2018, October 1). Bolsonaro defende o fim do Ministério do Meio Ambiente. OECO. Retrieved November 25, 2019 from https://www.oeco.org.br/reportagens/bolsonaro-defende-o-fimdo-ministerio-do-meio-ambiente/.

Busato, P. C. (2019). O Leviatã de Brumadinho. Boletim IBCCRIM, 27(316)

Čapek, S. M. (1993). The "environmental justice" frame: A conceptual discussion and an application. Social Problems, 40(1). Special Issue on Environmental Justice.

Carvalho, H. M. (2013). A expansão do capitalismo no campo e a desnacionalização do agrário no Brasil. Boletim Dataluta, dezembro, 1-9. http://www2.fct.unesp.br/grupos/nera/artigodomes/ 12artigodomes_2013.pdf.

Comissão Pastoral da Terra (2021). Conflitos no campo: Brasil 2020. Centro de Documentação. https://www.cptnacional.org.br/index. php/publicacoes-2/conflitos-no-campo-brasil

Comunicado n. 73376712020 (GABIN) (DOE) (Bra). https://www. gov.br/ibama/pt-br/centrais-de-conteudo/2020-04-03-sei-ibama7337671-comunicado-pdf

Comunicado n. 87536132020 (GABIN) (DOE) (Bra). https://www. gov.br/ibama/pt-br/acesso-a-informacao/publicacoes-ofici ais/comunicado-no-8753613-2020-gabin-de-13-de-novem bro-de-2020

Conselho Indígena Missionário - Cimi. (2019). Relatório - Violência contra povos indígenas no Brasil: dados de 2018. Retrieved October 28, 2019 from https://cimi.org.br/observatorio-da-viole ncia/edicoes-anteriores/.

Conselho Indígena Missionário - Cimi. (2021a). Ataques armados de garimpeiros continuam na TI Yanomami e provocam a morte de duas crianças indigenas. Retrieved September 20, 2021 from https://cimi.org.br/2021/05/ataques-armados-garimpeiros-conti nuam-ti-yanomami-provocam-morte-duas-criancas-indigenas/

Conselho Indígena Missionário - Cimi. (2021b). Em série de ataques, seguranças privados queimam casas Guarani Kaiowá em Doura$\operatorname{dos}(M S)$. Retrieved September 20, 2021 from https://cimi.org. br/2021/09/ataques-segurancas-privados-queimam-casas-guara ni-kaiowa-dourados-ms/

Conselho Indígena Missionário - Cimi. (2021c). Hutukara denuncia, em Nota, morte de duas crianças Yanomami em decorrência do garimpo. Retrieved September 20, 2021 from https://cimi.org. br/2021/10/hutukara-denuncia-em-nota-morte-de-duas-criancasyanomami-em-decorrencia-do-garimpo/

Decreto n. 8.127 2013 (PR) (DOE) (Bra). http://www.planalto.gov.br/ ccivil_03/ato2011-2014/2013/decreto/d8127.htm

Decreto n. 9.844 2019 (PR) (DOE) (Bra). http://www.planalto.gov.br/ ccivil_03/_ato2019-2022/2019/decreto/D9844.htm

Decreto n.9.845 2019 (PR) (DOE) (Bra). http://www.planalto.gov.br/ ccivil_03/_ato2019-2022/2019/decreto/D9845.htm
Decreto n.9.846 2019 (PR) (DOE) (Bra). http://www.planalto.gov.br/ ccivil_03/ ato2019-2022/2019/decreto/D9846.htm

Decreto n. 10.4732020 (PR) (DOE) (Bra). http://www.planalto.gov. br/ccivil_03/ ato2019-2022/2020/decreto/D10473.htm

Decreto n.10.627 2021 (PR) (DOE) (Bra). http://www.planalto.gov. br/ccivil_03/_ato2019-2022/2021/decreto/D10627.htm

Decreto n.10.628 2021 (PR) (DOE) (Bra). http://www.planalto.gov. br/ccivil_03/_ato2019-2022/2021/decreto/D10628.htm

Decreto n.10.629 2021 (PR) (DOE) (Bra). http://www.planalto.gov. br/ccivil_03/_ato2019-2022/2021/decreto/D10629.htm

Decreto n.10.630 2021 (PR) (DOE) (Bra). http://www.planalto.gov br/ccivil_03/_ato2019-2022/2021/decreto/D10630.htm

Dias, F. V. \& Budó, M. N. (2019). Criminologia verde e a responsabilidade do estado no esvaziamento do licenciamento ambiental na política nacional do meio ambiente. Meritum: Revista de Direito da Universidade FUMEC, 14(1).

Diegues, A. C. (2008). O mito moderno da natureza intocada. (6.ed.). Hucitec, Nupaub.

Estado de Minas. (2020, November 17). Governo Bolsonaro flexibilizou exigências para exportação de madeira brasileira. Estado de Minas. Retrieved May 23, 2021 from https://www.em.com. br/app/noticia/nacional/2020/11/17/interna_nacional,1207081/ governo-bolsonaro-flexibilizou-exigencias-para-exportacaode-madeira-b.shtml

Fearnside, P. M. (2006). Desmatamento na Amazônia: dinâmica, impactos e controle. Acta Amazonica, 36(3).

Fearnside, P. M. (2018). Why Brazil's new president poses an unprecedented threat to the Amazon. 360 Yale environment. Retrieved November 4, 2019 from https://e360.yale.edu/ features/why-brazils-new-president-poses-an-unpreceden ted-threat-to-the-amazon.

Feliciano, G. G. \& Pasqualeto, O. Q. F. (2019). Meio ambiente laboral equilibrado: Análise do caso Brumadinho. Veredas do Direito, 16 (36). https://doi.org/10.18623/rvd.v16i36.1556

Ferrante, L. \& Fearnside, P. M. (2019). Brazil's new president and 'ruralists' threaten Amazonia's environment, traditional peoples and the global climate. Environmental conservation, 2. Retrieved November 4, 2019 from https://www.cambridge.org/core/journ als/environmental-conservation/article/brazils-new-presidentand-ruralists-threaten-amazonias-environment-traditional-peopl es-and-the-global-climate/F5C1E42BF9F6E6BDDB957B876 01FC4F7.

Folha de S. Paulo. (2019, February 28). Ricardo Salles exonera 21 dos 27 superintendentes regionais do Ibama. Folha de S. Paulo. Retrieved October 31, 2019 from https://www1.folha.uol.com.br/ ambiente/2019/02/ricardo-salles-exonera-21-dos-27-superinten dentes-regionais-do-ib.shtml.

Folha de S. Paulo (2021, January 28). Consórcio de veículos de imprensa lança campanha em prol da vacina contra a Covid-19. Folha de S. Paulo. Retrieved February 13, 2021 from https:// www1.folha.uol.com.br/equilibrioesaude/2021/01/consorciode-veiculos-de-imprensa-lanca-campanha-em-prol-da-vacinacontra-a-covid-19.shtml.

Fundação de Amparo à Pesquisa do Estado de São Paulo (2020, October). Recorde de queimadas no Pantanal em 2020. Pesquisa Fapesp, 296. Retrieved January 28, 2021 from https://revistapes quisa.fapesp.br/recorde-de-queimadas-no-pantanal-em-2020/.

G1. (2019, September 24). Veja a íntegra do discurso de Bolsonaro na abertura da Assembleia Geral da ONU. G1. Retrieved October 28, 2019 from https://g1.globo.com/mundo/noticia/2019/09/24/ veja-a-integra-do-discurso-de-bolsonaro-na-abertura-da-assem bleia-geral-da-onu.ghtml.

G1. (2020, August 27). Óleo no litoral: um ano depois, Marinha conclui investigação sem apontar culpados ou origem do desastre. G1. Retrieved January 29, 2021 from https://g1.globo.com/pe/perna mbuco/noticia/2020/08/27/oleo-no-litoral-um-ano-depois-marin 
ha-conclui-investigacao-sem-apontar-culpados-ou-origem-dodesastre.ghtml.

Girardi, G. (2019, July 19). Bolsonaro acusa Inpe de divulgar dados mentirosos sobre desmatamento. O Estado de S. Paulo. Retrieved October 28, 2019 from https://sustentabilidade.estadao.com.br/ noticias/geral,bolsonaro-acusa-inpe-de-divulgar-dados-menti rosos-sobre-desmatamento,70002929326.

Girardi, G. (2021, January 22). Orçamento previsto para o Meio Ambiente em 2021 é o mais baixo do século, alerta ONG. Terra. Retrieved January 29, 2021 from https://www.terra.com.br/notic ias/ciencia/sustentabilidade/orcamento-previsto-para-o-meioambiente-em-2021-e-o-mais-baixo-do-seculo-alerta-ong,8709f 25a828037246877d6a2efab8fcf58lupoje.html.

Greenpeace Brasil v. Ricardo Salles, STF, Plenário, Pet.8481 DJE n.270, 2019.

Hellman, J. (2014). The fifth crime under international criminal law: ecocide? In D. Brodowski, M. E. M. Parra, K. Tiedemann \& Vogel, J. (Eds.), Regulating corporate criminal liability (pp. 273-280). Springer.

Homero, V. (2020, August 14). Dados oficiais de covid-19 e do consórcio de imprensa variam menos que $1 \%$. Poder 360 . Retrieved February 13, 2021 from https://www.poder360.com.br/coron avirus/dados-oficiais-de-covid-19-e-do-consorcio-de-impre nsa-variam-menos-que-1/.

Hylliard, P. \& Tombs, S. (2013). ¿Más allá de la criminología? Revista Crítica Penal y Poder, 4.

Instituto Nacional de Pesquisas Espaciais. (2019). Programa queimadas. Retrieved October 28, 2019 from http://queimadas.dgi.inpe. br/queimadas/portal-static/situacao-atual/.

Instituto Nacional de Pesquisas Espaciais. (2021a). Programa queimadas. Retrieved May 23, 2021 from https://queimadas.dgi.inpe.br/ queimadas/portal-static/estatisticas_estados/.

Instituto Nacional de Pesquisas Espaciais. (2021b). Programa queimadas. Retrieved January 28, 2021 from http://queimadas.dgi.inpe. br/queimadas $/ \mathrm{aq} 1 \mathrm{~km} /$.

Instrução Normativa n.104 2021 (MAPA) (INCRA) (DOE) (Bra). https://www.in.gov.br/en/web/dou/-/instrucao-normativa-n-104de-29-de-janeiro-de-2021-301790223

Junqueira, D. (2019, June 2). Em meio a apagão 'médico' indígena, 3 crianças morrem em 11 dias no Xingu. Repórter Brasil. Retrieved October 28, 2019 from https://reporterbrasil. org.br/2019/06/em-meio-a-apagao-medico-indigena-3-crian cas-morrem-em-11-dias-no-xingu/.

Lei n. 7.3471985 (Cn) (DOE) (Bra). http://www.planalto.gov.br/ccivil_ 03/leis/17347orig.htm

Lei n. 8.4291992 (Cn) (DOE) (Bra). http://www.planalto.gov.br/ccivil_ 03/leis/18429.htm

Lei n. 9.8821999 (Cn) (DOE) (Bra). http://www.planalto.gov.br/ccivil_ 03/leis/19882.htm

Lei n. 9.605 1998 (Cn) (DOE) (Bra). http://www.planalto.gov.br/ccivil_ 03/leis/19605.htm

Lencioni, S. (2012). Acumulação primitiva: um processo atuante na sociedade contemporânea. In Revista Franco-Brasileira de Geografia. https://doi.org/10.4000/confins.7424

Londoño, E. (2019, August 2). Bolsonaro Fires Head of Agency Tracking Amazon Deforestation in Brazil. The New York Times. Retrieved October 28, 2019 from https://www.nytimes.com/ 2019/08/02/world/americas/bolsonaro-amazon-deforestationgalvao.html.

Maisonnave, F. (2019, March 28). Ibama exonera servidor que multou Bolsonaro por pesca irregular. Folha de S. Paulo. Retrieved October 31, 2019 from https://www1.folha.uol.com.br/ambie nte/2019/03/ibama-exonera-servidor-que-multou-bolsonaropor-pesca-irregular.shtml.

Martins, J.S. (1993). A chegada do Estranho. Hucitec.
Martins, J.S. (2019). Fronteira. Contexto.

Michalowski, R. J. \& Kramer, R. C. (2007). State-corporate crime and criminological inquiry. In H. N. Pontell \& Geis, G. (Eds.), International handbook of white-collar and corporate crime (pp. 200-222) Springer.

Ministério da Agricultura, Pecuária e Abastecimento. (2021). Informações Técnicas. Retrieved September 20, 2021 from https:// www.gov.br/agricultura/pt-br/assuntos/insumos-agropecuarios/ insumos-agricolas/agrotoxicos/informacoes-tecnicas

Natali, L. (2014). Green criminology, victimización medioambiental y social harm. El caso de Huelva (España). Revista Crítica Penal $y$ Poder, 7.

Office of the Prosecutor (2016). Policy paper on case selection and prioritization. Retrived February 6, 2020 from https://www.icccpi.int/itemsDocuments/20160915_OTP-Policy_Case-Selection_ Eng.pdf.

Paloschi, D. R. (2019). As violências contra os povos indígenas tornaram-se chagas institucionalizadas. In Conselho Indígena Missionário - Cimi. Relatório - Violência contra povos indígenas no Brasil: dados de 2018. (pp. 9-10). Retrieved October 28, 2019 from https://cimi.org.br/observatorio-da-violencia/edico es-anteriores/.

Peixoto, J. F. (2021, June 7). Governo Bolsonaro quer formar milícia ambiental na Amazônia. in Impacto Ambiental. Retrieved July 28, 2021 from https://www.impactounesp.com.br/post/governobolsonaro-quer-formar-mil\% C3\%ADcia-ambiental-na-amaz\% C3\%B4nia.

Phillips, D. (2019, January 2). Jair Bolsonaro launches assault on Amazon rainforest protections. The Guardian. Retrieved October 28, 2019 from https://www.theguardian.com/world/2019/jan/02/ brazil-jair-bolsonaro-amazon-rainforest-protections.

Plan de Sánchez Massacre v. Guatemala. (2004). Serie C 166 Rep. (CIDH). http://www.corteidh.or.cr/docs/casos/articulos/seriec_ 116_ing.pdf.

Prata, D. A. (2019). Criminalidade corporativa e vitimização ambiental: análise do caso Samarco. LiberArs.

Prefeitura de Florianópolis v. Ministério Público Federal. (2014). TRF-4. Quarta Turma. Proc.n.0000574-90.2009.404.7200 (Bra).

Resende, S. M. (2018, November 5). 'No que depender de mim, não tem mais demarcação de terra indígena', diz Bolsonaro a TV'. Folha de S. Paulo. Retrieved October 28, 2019 from https:// www1.folha.uol.com.br/poder/2018/11/no-que-depender-demim-nao-tem-mais-demarcacao-de-terra-indigena-diz-bolso naro-a-tv.shtml.

Resolução n. 2842001 (CONAMA) (DOE) (Bra).

Resolução n. 3022002 (CONAMA) (DOE) (Bra).

Resolução n. 3032002 (CONAMA) (DOE) (Bra).

Revista Fórum (2019, August 3rd). Diretor demitido do Inpe diz que era poribido de disparar alertas sobre desmatamento. Revista Fórum. Retrieved October 28, 2019 from https://revistaforum. com.br/politica/bolsonaro/diretor-demitido-do-inpe-diz-que-eraproibido-de-disparar-alertas-sobre-desmatamento/\#

Rome Statute of the International Criminal Court, (last amended 2010), 17 July 1998. https://www.icc-cpi.int/resource-library/docum ents/rs-eng.pdf.

Saad-Diniz, E. (2019a). Justicia restaurativa y desastres socioambientales en Brasil. In F. Figueroa, E. Saad-Diniz, M. Parra, A. Trindade \& Kleiman, H. (Eds.), RIDP libri 04: Alternativas al sistema de justicia criminal latinoamericano: V Simpósio de Jóvenes Penalistas de la Asociación Internacional de Derecho Penal (pp. 9-25) Maklu.

Saad-Diniz, E. (2019b). Vitimologia corporativa. Tirant lo Blanch.

Saad-Diniz, E. (2020). Vitimização corporativa e dependência comunitária na criminologia ambiental: o acerto de contas com os desastres ambientais. Boletim IBCCRIM, 327. Retrieved May 23, 
2021 from https://www.ibccrim.org.br/publicacoes/edicoes/6/12. http://hdl.handle.net/1765/98179.

Sauer, S., \& Borras, S. M., Jr. (2016). 'Land grabbing' e 'green grabbing': uma leitura da 'corrida na produção acadêmica' sobre a apropriação global de terras. Campo-Território: Revista De Geografia Agrária, 11(23), 6-42.

Schlosberg, D. (2004). Reconceiving environmental justice: Global movements and political theories. Environmental Politics. https:// doi.org/10.1080/0964401042000229025

Seto, G. (2018, October 9). Bolsonaro diz que pretende acabar com 'ativismo ambiental xiita' se for presidente. Folha de S. Paulo. Retrieved October 28, 2019 from https://www1.folha.uol.com. br/poder/2018/10/bolsonaro-diz-que-pretende-acabar-com-ativi smo-ambiental-xiita-se-for-presidente.shtml.

Shalders, A. (2019, August 24). Queimadas disparam, mas multas do Ibama despencam sob Bolsonaro. BBC News Brasil. Retrieved October 31, 2019 from https://www.bbc.com/portuguese/brasil49430376.

Sieders, L. J. (2020). The battle of realities: The case for and against the inclusion of 'Ecocide' in the ICC Rome Statute. RIDP, 91(1)

Stival, M. M. (2018). Direito internacional do meio ambiente: o meio ambiente na jurisprudência das Cortes Internacionais de Direitos Humanos. Editorial Juruá.

Tavares, J. \& Maisonnave, F. (2019, January 9). Ibama anula multa ambiental de Bolsonaro, e processo volta à estaca zero. Folha de S. Paulo. Retrieved October 31, 2019 from https://www1.folha. uol.com.br/ambiente/2019/01/ibama-anula-multa-ambiental-debolsonaro-e-processo-volta-a-estaca-zero.shtml.

Vergara-Camus, L \& Kay, C. (2018). La economía política agraria de los gobiernos de izquierda en América Latina: El agronegocio, el campesinado y los límites del neodesarrollismo. In K. VergaraCamus \& Kay, C. (Comp.), La cuestión agraria y los gobiernos de izquierda en América Latina: Campesinos, agronegocio y neodesarrollismo (pp. 349-396) Clacso.

Vicente Martínez, R. (2018). Hacia un derecho penal internacional medioambiental. In E. Demetrio Crespo \& Nieto Martin, A. (Dir.), Derecho penal económico y derechos humanos (pp. 245278) Tirant lo Blanch.

Watanabe, P. (2018, November 1). Bolsonaro recua de fusão de Ambiente e Agricultura e diz não querer xiita ambiental. Folha de $S$. Paulo. Retrieved October 28, 2019 from https://www1.folha.uol. com.br/ambiente/2018/11/bolsonaro-recua-em-fusao-de-meioambiente-e-agricultura-e-diz-nao-querer-xiita-ambiental.shtml.

Weistein, S. \& Moegenburg S. (2004). Açaí Palm Management in the Amazon Estuary: course for conservation or passage to plantations? Conservation \& Society, 2(2), Special Issue: Non-Timber Forest Products, 315-346. https://www.jstor.org/stable/26396631

White, R. (2008). Crimes against nature: Environmental criminology and ecological justice. Willian Publishing.

White, R. (2013). Environmental harm: An eco-justice perspective. Policy Press.

White, R. \& South, N. (2013). The future of green criminology: Horizon scanning and climate change. Retrieved 24 May 2021 from https://www.researchgate.net/publication/263194809_THE_ FUTURE_OF_GREEN_CRIMINOLOGY_HORIZON_SCANN ING_AND_CLIMATE_CHANGE_Rob_White_and_Nigel_ South.

Whyte, K. P. (2016). Indigenous experience. Environmental Justice and Settler Colonialism. https://doi.org/10.2139/ssrn.2770058 